Journal of Southeast Asian

2011

\title{
Hmong Daughter; Womyn
}

Linda Hawj

Metropolitan State University, linda.her@gmail.com

Follow this and additional works at: https://docs.lib.purdue.edu/jsaaea

\section{Recommended Citation}

Hawj, Linda (2011) "Hmong Daughter; Womyn," Journal of Southeast Asian American Education and Advancement: Vol. 6 : Iss. 1, Article 26.

DOI: $10.7771 / 2153-8999.1042$

Available at: https://docs.lib.purdue.edu/jsaaea/vol6/iss1/26

This document has been made available through Purdue e-Pubs, a service of the Purdue University Libraries. Please contact epubs@purdue.edu for additional information.

This is an Open Access journal. This means that it uses a funding model that does not charge readers or their institutions for access. Readers may freely read, download, copy, distribute, print, search, or link to the full texts of articles. This journal is covered under the CC BY-NC-ND license. 


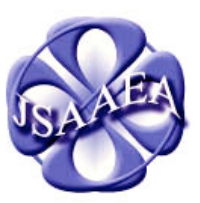

Volume 6 (2011)

\section{Journal of Southeast Asian American Education \& Advancement}

WWw.JSAAEA.org
A peer-reviewed scholarly journal published by the National Association for the Education \& Advancement of Cambodian, Laotian, and Vietnamese Americans (NAFEA)

\title{
Hmong Daughter; Womyn
}

\author{
Linda Hawj \\ Metropolitan State University
}

Mom and dad, I can see that I'm just a Hmong daughter to you;

A Hmong womyn.

I'm not a son; I'm not a man,

but I can share with you

and I can show you what, mankind can't.

Success and happiness

doesn't only come in the form of a son, a man.

\section{Because:}

I can sweep away the clouds and give you the light of the sun, I can quench your thirst and carry you gallons of the ocean,

I can build you shelter; gardens and show you resources of the earth, I can create art; life and make wonders of the stars,

I can fill your hunger up and give you the riches by the wealth of my love.

But that can only be a reality to you

If you,

open up to receive me, welcomingly

as your daughter; a womyn.

\section{$\Theta$}

SORERIGHISRESEREDReaders are free to copy, display, and distribute this article, as long as the work is attributed to the author(s) and the Journal of Southeast Asian American Education \& Advancement, it is distributed for noncommercial purposes only, and no alteration or transformation is made in the work. More details of this Creative Commons license are available at http://creativecommons.org/licenses/by-nc-nd/3.0/. All other uses must be approved by the author(s) or JSAAEA. 


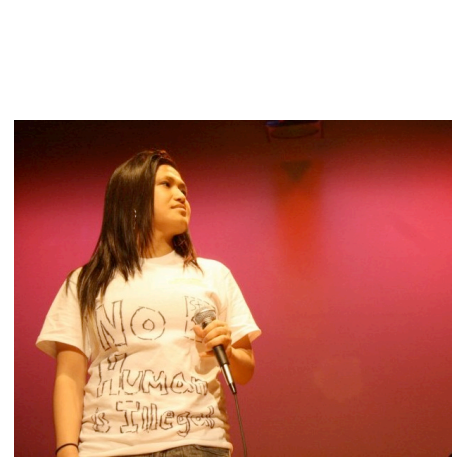

\begin{abstract}
About the Author
Artist Activist. Linda Hawj is an emerging, multi-disciplined Artist in the forms of writing, poetry, spoken word, hip hop emcee and filmmaking. As an Activist, she advocates for the equity of Hmong LGBTQI community, gender and racial justice, exploring and understanding identities of the self as well as self-empowerment. She pairs her love for Art and passion for humanitarian work as social and cultural changing tools; she creatively expresses and actively speaks out to evoke awareness, access and change. She is
\end{abstract} currently pursing an Individualized BA in Artist Activism at Metropolitan State University. 


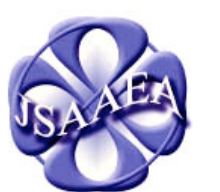

Volume 6 (2011)

\section{Journal of Southeast Asian American Education \& Advancement}

\author{
WWW.JSAAEA.org
}

\section{Editor}

Dr. Wayne E. Wright

University of Texas, San Antonio

\section{Associate Editors}

Dr. Chhany Sak-Humphry

University of Hawaii

Dr. KimOanh Nguyen-Lam

California State University, Long Beach

Book Review Editor

Dr. Vichet Chhuon

University of Minnesota

\section{Creative Works Editor}

Bryan Thao Worra

Lao Assistance Center

Special Advisor

Gregory Green

Curator, Echols Collection on Southeast Asia, Cornell University Library

Journal Manager

Sovicheth Boun

University of Texas, San Antonio
A peer-reviewed

scholarly journal published by the

National Association

for the Education \&

Advancement of

Cambodian, Laotian,

and Vietnamese

Americans (NAFEA)

Comments and questions for the editorial staff may be directed to jsaaea@1ists.sis.utsa.edu

\section{Editorial Review Board}

\author{
Dr. Steve Arounsack \\ California State University, Stanislaus \\ Dr. Phala Chea \\ Lowell Public Schools \\ Dr. Loan Dao \\ Cancer Prevention Institute of California \\ Dr. Sophal Ear \\ U.S. Naval Postgraduate School \\ Dr. Nancy H. Hornberger \\ University of Pennsylvania \\ Dr. Peter Nien-Chu Kiang \\ University of Massachusetts, Boston
}

Dr. Carl L. Bankston III

Tulane University

Dr. George Chigas

University of Massachusetts, Lowell

Dr. Changming Duan

University of Missouri, Kansas City

Dr. Jeremy Hein

University of Wisconsin - Eau Claire

Dr. Samlong Inthaly

Minneapolis Public Schools

Dr. Kevin K. Kumashiro

University of Illinois, Chicago 

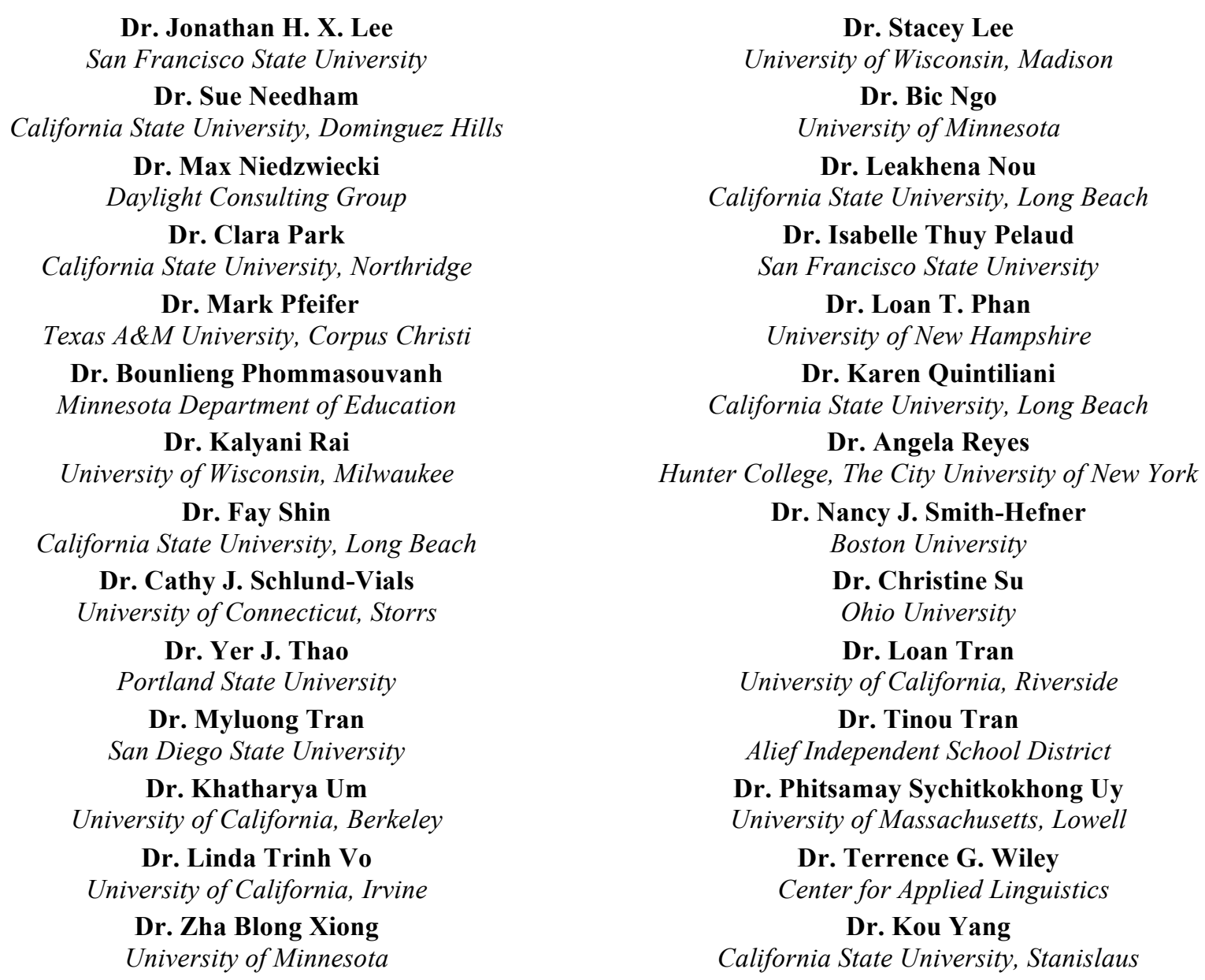

\section{Doctoral Student Editorial Review Board}

\author{
Keo Chea-Young \\ University of Pennsylvania \\ Ketmani Kouanchao \\ California State University, Fullerton \\ Polinda Keo \\ University at Albany \\ Ravy Lao \\ University of California, Santa Barbara \\ Thien-Huong Ninh \\ University of Southern California \\ Malaphone Phommasa \\ University of California, Santa Barbara \\ Rassamichanh Souryasack \\ University of California, Santa Barbara \\ Alisia Tran \\ University of Minnesota \\ Silvy Un \\ University of Minnesota
}

\author{
Annie BichLoan Duong \\ San Joaquin County Office of Education \\ Peter Tan Keo \\ Columbia University \\ Ha Lam \\ Arizona State University \\ Monirith Ly \\ Texas State University-San Marcos \\ Giang Pham \\ University of Minnesota \\ Vanna Som \\ Harvard University \\ Somongkol Teng \\ University of Minnesota \\ Krissyvan Truong \\ Claremount Graduate University \\ Yang Sao Xiong \\ University of California, Los Angeles
}

